\title{
Digital Collaboration in Teaching and Learning Activities: The Reflexivity Study on Educational Digital Empowerment
}

\author{
Irwansyah* \\ Communication Department, Universitas Indonesia, Jakarta \\ https://orcid.org/0000-0002-5047-1746 \\ Sofiatul Hardiah \\ Anthropology Department, Universitas Indonesia, Depok \\ https://orcid.org/0000-0002-8910-9170
}

\begin{abstract}
This research examines digital empowerment in high schools in Indonesia. Based on the reflexivity perspective, digital empowerment is described as the effort to respond to changes in learning systems in digital-based schools. This research was conducted qualitatively through observations and in-depth interviews. The participants of this study included school principals and the teachers of information and communication technology in three Indonesian public senior high schools in different cities, namely Banda Aceh, Padang, and Banjarmasin. The results highlighted the need to understand the context and projections of the teachers' and student's ability and self-access to information and communication technology elements, in which appropriate measures can be formulated in response to the digitisation of the teaching-learning process in the schools. Self-awareness and information and communication technology competence shape digital empowerment efforts in schools based on their respective needs and abilities. As such, the digital-based collaboration of teaching and learning can be construed as a form of contextual digital empowerment, which is applied at the micro-level adapting to dynamic changes in digital competence, especially in teachers and students.
\end{abstract}

Keywords: Information and communication technology; digital empowerment; collaboration; education

\section{Introduction}

The integration of technology in the learning process encourages teachers and students to adapt new media in the teaching-learning and communication process

*Corresponding author: Irwansyah, email: irwansyah09@ui.ac.id 
(Casal, 2007). Information and communication technology (ICT) are advantageous in various ways. For instance, it provides a lifetime learning space (Aubert, 2013), and brings about a change of role in teaching-learning activities, allows access to internet-based learning materials and information, eliminates space-time limitations, supports education, and opens opportunities for the collaboration of teachers and students (Fitriyadi, 2013).

Government policies and the efforts of school management to incorporate ICT in schools' teaching-learning process (Ekayanti \& Irwansyah, 2019) are laudable. The process improves the attitudes of teachers' and students' towards learning because self-control and focus are practised for the proper use and application of computer technology (Teo, 2008). Teachers' competence in interacting with ICT devices (Weckert \& Lucas, 2017) tends to be in line with the level of experience acquired, boosting their confidence in using technology-related tools.

Likewise, self-confidence in using ICT devices arises from the teachers' persistence in understanding how to use such devices and ICT competencies of students (Ekayanti \& Irwansyah, 2019). Moreover, ICT allows teachers to balance the perceptions and competencies of educated ICT students (Jones, 2004), and also helps teachers improve ICT-based teaching productivity (Sánchez \& Alemán, 2011). In addition, teachers and students can exchange understanding around ICT and competence to shape creative and effective learning outcomes (Birch \& Irvine, 2009; Honan, 2008).

The tendency of students to use the internet for personal needs necessitates integrating digital technology in order to enhance activities and behaviour more positively (Austin, 2017). Three measures can be applied to support and produce meaningful changes in the teaching-learning process, which include building collaborative structures, effective technology use models, and reflection on the practices and beliefs lived (Ertmer, 1999). Furthermore, autonomy, capability, and creativity are required to develop the quality of ICT-based teaching and learning. As such, it is essential to develop training for teachers to refine and hone their competence and creativity in using ICT tools. This ability is useful for modifying effective learning material in this digital age (Lowther, Inan, Strahl, \& Ross, 2008).

The implementation of the 2013 Curriculum (Hermawati, 2020) in Indonesia, projects the government's efforts and intention to accommodate the role of ICT to improve the quality of education (Fitriyadi, 2013). Moreover, the curriculum can be effectively implemented with the view that teachers and students are ICTcompetent and literate. The integration of ICT in the learning process should consequently model teachers into facilitators, collaborators, mentors, trainers, directors, and study partners while providing students with great choices and responsibilities to experience learning events (UNESCO, 2007). This integration makes students in many respects, the centre of learning, sharpening their communication, problem-solving, critical thinking, creativity, adaptive and reflective skills (Gray, 2003).

There is no doubt that teachers experience obstacles in integrating ICT in learning due to internal and external factors (Ertmer, 1999, 2003). External barriers relate to time, support, resources, and training provided by the school, while internal 
obstacles include attitude, self-confidence, and the willingness to try. However, these barriers can be overcome by acting on the need for ICT facilities by schools, offering ICT training to teachers, and collaboration between teachers and students (Samuel \& Zaitun, 2007).

The obstacles encountered by teachers and students in responding to changes in learning systems are attributed to unpreparedness in terms of ICT knowledge and practice. These blocks or obstacles call for digital empowerment efforts by teachers and students to create effective ICT-based teaching and learning activities. In the context of Indonesia, digital empowerment in education has not been extensively undertaken or enacted, especially from the reflexivity perspective. Therefore, this research examines how reflexivity functions in digital empowerment in Indonesian high schools.

\section{Literature Review}

\subsection{Digital Empowerment}

The concept of empowerment originated as a reaction to the power imbalance in society (Hage \& Lorensen, 2005). It is a multidimensional social learning process that controls life using knowledge and ability (Payne, 1997; Saleebey, 2006), and occurs in individual and community contexts. Empowerment also relates to how people think and consider themselves, their capacities, abilities, and mastery over what they have (Staples, 1990). The community context shows the psychological cognition of a group of people in response to challenges and the capacity to change their social positioning by participating in collective actions and helping others (Boehm \& Staples, 2004). Group empowerment is achieved through collaborative effort (Hur, 2006).

Information and communication technology (ICT) is rapidly evolving in today's society by facilitating connections among different communities (Mäkinen, 2006). The process of digital integration occurs within the spheres of consequential and dynamic digital empowerment (Safira \& Irwansyah, 2019). The indicators of empowerment include technology awareness, motivation in technological devices, technical access to digital technology, competence in using technology, and constructive participation in creating interactive roles (Kuyoro, Awodele, \& Samuel, 2012).

\subsection{Reflexivity}

Reflexivity defines the character of all human behaviours with a fundamental identity that continues to be reproduced and modified over time, along with life changes. Giddens used the expression "reflexive monitoring" of action to describe human behaviours that change consistently but continue to reflect essential traits (Giddens, 1990). The concept of reflexivity emerges from individual responses based on quick life changes (Cohen-Cole, 2005).

The concept of reflexivity underlines an individual's response to a given situation with a particular impact on one's life. The effect occurs in the context of selfdevelopment and the availability of choices for the individual's future (Giddens, 1990). Reflexivity is a process of self-definition based on social and psychological information in the dynamics of life, resulting in active and creative actions in response to life changes (Elliott, 2014). 
The rapid change in people's lives has two value sides. However, there is both an opportunity as well as a danger due to overlapping situations and choices in life. Changes cannot be avoided or appropriately addressed due to the unpreparedness of information and knowledge (Ferguson, 1997). As such, reflexivity is an essential component for individuals to respond to life changes and provides an opportunity for individuals to shape themselves and their lives. Indeed, reflexivity is having the competence to act in the world, reflected through the formation and reshaping of actions and identities (Ferguson, 2003).

\section{Research Methodology}

A qualitative method is employed in this study using in-depth interview techniques for data collection. These techniques are appropriate in studying a group of individuals' behaviour in response to a phenomenon (Alshenqeeti, 2014; Baker, 2006). There are two categories of informants in this study, namely school principals and ICT teachers. Each is represented by one principal, three to six ICT teachers, and between eight to 12 students. The information provided in this study explains teachers, students, and school authorities' behaviour regarding education digitalisation and empowerment. The implementation in this study was based on three stages: (1) Gathering initial information on high schools that implemented ICT-based learning. The search for necessary information was not limited to the sites provided by the search engine (Levene, 2010); (2) Visiting three high schools identified as research locations, specifically public senior high schools in Banda Aceh (SMA Lab School), Padang (SMAN3), and Banjarmasin (SMAN9). The schools selected from institutions that had integrated ICT since the enactment of the 2013 Curriculum. ICT lessons at the junior and senior secondary levels were replaced as extracurricular activities in the schools; (3) Conducting indepth interviews with the informants to obtain information on several research questions such as the availability of technology-based facilities, technology-based learning activities, and digital empowerment efforts in the teaching-learning process.

Reflexivity provides a perspective on digital empowerment having a variety of data patterned on the following themes (Giddens, 1990): (1) ICT Technical access, (2) ICT awareness of teachers and students, (3) ICT motivation of teachers and students, (4) ICT initiative of teachers and students, (5) ICT competence of teachers and students, (6) ICT barrier of teachers and students, and (7) Digital empowerment efforts of teachers and students

The coding process of the primary data was carried out in three stages: open, axial, and selective coding (Miles \& Huberman, 1994). Selective coding shows informant behaviour repetition, which was grouped as a theme in answering the research questions (Irwansyah \& Triputra, 2016). The data analysis was conducted using a thematic approach to identify, analyse, and determine a specific social phenomenon theme (Braun \& Clarke, 2006). The data and results were validated by triangulating qualitative and quantitative data communication between researchers and supplementing secondary data accessed through online literature in order to obtain a holistic explanation (Yeasmin \& Rahman, 2012). 


\section{Research Findings}

Digital technology involvement in the three schools occurred in several forms, including the availability of digital access, extracurricular facilities, and ICT-based competitions. The integration of ICT can be seen in teachers' and students' ICT competencies in the teaching-learning process. Interestingly, teacher-student ICT competencies were at different levels, based on individual ICT access, motivation, and initiative. This gap in ICT competencies was addressed by seeking digital empowerment facilitated by the school authorities and teachers and students directly in their daily interactions.

\subsection{Digital Access at School}

Digital access in the context of a school demonstrates its technological awareness and motivation related to the teaching-learning process, achieved through the availability of ICT facilities, extracurricular and ICT-based competitions and the implementation of teaching and learning activities in digital-based classes. Table 1 summarises the information on digital access in the three schools of this study.

Table 1 shows the similarity in the provision of ICT-based facilities, specifically computer laboratories, and limited internet $\mathrm{Wi}$-Fi access in specific locations, such as public senior high school (Sekolah Menengah Atas - SMA) Computer laboratories and Wi-Fi access were used in teaching and learning activities within set times and rules. The schools implemented technological awareness and motivation through digital-based activities.

Table 1: Information Technology and Facilities Based Activities in Several Public Senior High Schools in Indonesia

\begin{tabular}{|c|c|c|c|}
\hline Facilities & $\begin{array}{l}\text { SMA Lab School in } \\
\text { Banda Aceh }\end{array}$ & SMAN3 in Padang & $\begin{array}{l}\text { SMAN9 in } \\
\text { Banjarmasin }\end{array}$ \\
\hline School Facilities & $\begin{array}{l}\text { Liquid Crystal Display } \\
\text { (LCD) in each class; } \\
\text { Wi-Fi; Computer } \\
\text { laboratory. }\end{array}$ & $\begin{array}{l}\text { Three computer } \\
\text { laboratories with } 35 \\
\text { computer units, } \\
\text { direct internet } \\
\text { access on each } \\
\text { personal computer } \\
\text { (PC), headset, and } \\
\text { study material via } \\
\text { digital video disc } \\
\text { (DVD). }\end{array}$ & $\begin{array}{l}\text { Two computer } \\
\text { laboratories with } \\
\text { a total of } 65 \\
\text { computer units; } \\
\text { wifi.id access. }\end{array}$ \\
\hline $\begin{array}{c}\text { ICT-Based } \\
\text { Extracurricular }\end{array}$ & $\begin{array}{l}\text { Computer } \\
\text { extracurricular } \\
\text { (compulsory for class } \\
\text { of 10); material on } \\
\text { how to access the } \\
\text { internet, determine } \\
\text { appropriate and safe } \\
\text { social media, } \\
\text { operating video } \\
\text { editing applications, } \\
\text { animation, screening, } \\
\text { and web design. }\end{array}$ & $\begin{array}{l}\text { Extracurricular } \\
\text { material, namely } \\
\text { design, } \\
\text { programming, and } \\
\text { cinematography. }\end{array}$ & $\begin{array}{l}\text { Extracurricular } \\
\text { material, namely } \\
\text { making email } \\
\text { and e-learning. }\end{array}$ \\
\hline
\end{tabular}




\begin{tabular}{|c|c|c|c|}
\hline Facilities & $\begin{array}{c}\text { SMA Lab School in } \\
\text { Banda Aceh }\end{array}$ & SMAN3 in Padang & $\begin{array}{c}\text { SMAN9 in } \\
\text { Banjarmasin } \\
\end{array}$ \\
\hline ICT-Based Contest & $\begin{array}{l}\text { Types of competitions: } \\
\text { cinematography/ } \\
\text { short films, and } \\
\text { graphic design/ } \\
\text { poster design. }\end{array}$ & $\begin{array}{l}\text { Types of } \\
\text { competitions, } \\
\text { including graphic } \\
\text { design and } \\
\text { computer } \\
\text { Olympiad. }\end{array}$ & $\begin{array}{l}\text { Types of } \\
\text { competition, } \\
\text { specifically, } \\
\text { poster design. }\end{array}$ \\
\hline \multirow[t]{2}{*}{ ICT-Based Subject } & $\begin{array}{l}\text { Use email and Google } \\
\text { Forms for } \\
\text { assignments; E-report } \\
\text { card. }\end{array}$ & Unknown & $\begin{array}{l}\text { Some subject } \\
\text { teachers, } \\
\text { including } \\
\text { English, } \\
\text { Sociology, } \\
\text { Mathematics, use } \\
\text { Google Translate, } \\
\text { Google, e-books, } \\
\text { and computer } \\
\text { laboratories for } \\
\text { teaching-learning } \\
\text { activities. }\end{array}$ \\
\hline & & & $\begin{array}{l}\text { Schools only } \\
\text { conduct } \\
\text { computer-based } \\
\text { examinations in } \\
\text { computer } \\
\text { laboratories. }\end{array}$ \\
\hline Other & Unknown. & $\begin{array}{l}\text { Personal activities } \\
\text { are based on digital } \\
\text { technology } \\
\text { students, such as } \\
\text { becoming a } \\
\text { Vlogger/YouTuber, } \\
\text { Blogger, and online } \\
\text { seller. }\end{array}$ & $\begin{array}{l}\text { A teacher } \\
\text { manages the } \\
\text { school's } \\
\text { YouTube, } \\
\text { Instagram, } \\
\text { Facebook, and } \\
\text { Website accounts } \\
\text { and applies } \\
\text { copyright in } \\
\text { producing } \\
\text { content. }\end{array}$ \\
\hline
\end{tabular}

Source: Irwansyah, 2020

These facilities provide opportunities and a place for students to learn about technology in education and develop interests and talents in ICT. The availability of technology-based facilities provides teachers access to explore their ability to design and deliver digital-based subject matter. For instance, senior public high school in Banda Aceh and Banjarmasin, teachers, and students are encouraged to use email and Google Forms in the teaching-learning process, such as sending school assignments. The school provides digital access through facilities and convenes extracurricular and digital-based competitions for students. The Ministry of Education and Culture of the Republic of Indonesia established the competition as an alternative to ICT learning in the 2013 Curriculum (K-13). In carrying out K-13, students communicate the knowledge acquired in the learning 
process to others, both orally and in written form. This is one approach of utilising network access to the internet to deepen their understanding (Ahmad, 2014).

Extracurricular materials are provided through Microsoft Office applications, accessing the internet, via social media, operating video editing applications, animation, screening, and web design. For this reason, supportive steps are taken to provide basic ICT knowledge and skills. The school supports students talented in specific ICT fields to participate in competitions, such as cinematography and graphic design. The application of K-13 changes the role of teachers from instructors to facilitators, in guiding ICT-based activities.

\subsection{Teachers ICT Competence}

Teachers and students have technological competencies having varying degrees of proficiency which is useful in developing technological devices through related experience and individual awareness. Furthermore, it aids motivation and related activities based on digital technology.

The findings from the study show that teachers and students used digital technology in their education ecosystem, though not all had acquired the motivation and competence needed to operate technological devices. In SMA Padang, $85 \%$ of teachers were shown to be proficient in operating Microsoft Word.

In SMA Banda Aceh, young civil servant teachers were shown to have good ICT competency since they selected educators to understand basic ICT knowledge. Elderly teachers, however, were not adept at using technological devices. Age barriers and physical inabilities account for this inexperience in the field of technology.

Subject teachers in SMA Banda Aceh and Padang having ICT competencies use digital-based classes, especially in the use of computers. Technology is utilised to provide a varied and enjoyable learning experience and atmosphere for students. Additionally, they use email technology or Google Drive to send assignments to students. Similarly, the teachers at SMA Banda Aceh use email and Google Form to minimise distraction in the learning process and provide convenience and variety in an atmosphere of learning for students. The school supports digital motivation by providing e-report-based facilities in making grading much easier.

In SMA Banjarmasin, out of 26 teachers, 16 were proficient in technology tools and applications. However, ten were not proficient given their older age. In this school, ICT-competent teachers help incompetent colleagues, given it is not a requirement for teachers to be proficient in using technological devices. However, they strive to distribute the technology capabilities of teachers equally.

About $10 \%$ of subject teachers with ICT competencies permit students to access technology devices. The 2013 Curriculum requires students to conduct a critical analysis of a case in a subject. Here, teachers digitising teaching and learning activities help students understand the learning material. For instance, teachers use Google Translate and Google search to translate text conversations or practice listening displayed on an overhead projector or LCD. 


\subsection{Students ICT Competence}

Student competencies in using technological devices are developed and shaped through their interactive learning experience using the technology each day; for example, some students own and use devices, such as smartphones and laptops. On the other hand, students with limited access to digital technology have low ICT competencies. Consequently, they face obstacles in understanding ICT material and digital empowerment that is provided and encouraged in schools.

In the three schools, students with ICT competence initially acquired ICT knowledge while in junior high school. However, their level of proficiency varied depending on the frequency of interaction with smartphone devices and PCs. Students with ICT competence typically use technological devices to achieve their daily needs in learning, entertainment, and talent development.

Notwithstanding, students access Google to find answers to questions and other subject matter during their break times. For informal learning, they tend to use ebooks accessed via PCs situated in school laboratories or smartphones. Moreover, they actively search for information on the internet to build social networks with students from other schools through social media. They also share information with teachers through digital communication applications in seeking directions or instructions in their learning.

Students at SMA Banda Aceh and Padang having ICT competencies utilise their skills in achieving personal development and creative needs, such as graphic design, cinematography, and uploading to YouTube, selling online, and for blogging. These students use digital communication applications, such as Line and Instagram, to build communication networks and working relationships with school alumni currently studying at universities.

However, there is a gap in ICT competencies between students in SMA Banjarmasin. About $25 \%$ of students do not own or have access to technological devices, given economic constraints. Teachers conduct assessment among students on different technological capabilities beginning from their first day at school. Although some students understand ICT material relatively easily, others need several in-depth explanatory sessions. The explanatory sessions are necessary since they cannot practice at home using a laptop or smartphone device. Students having no or little access to technology devices often have slow learning rhythms when using ICT.

There is also the transformation of student learning behaviour due to the rapid development and emergence of advanced technologies, shaping them into digital generations or being digital naïve. This generation is dominated by digital devices, especially to access information. For this reason, it tends to have more significant learning opportunities than previous generations (Prensky, 2001). The development of digital technology among students and teachers can be further facilitated through digital access, such as through ICT knowledge, facilities, and opportunities to practice ICT in daily activities. Students and teachers with limitations in accessing these facilities face significant obstacles in ICT-based teaching and learning activities. Therefore, there is a need for increased digital accessibility for students and teachers to address their digital needs. 


\subsection{Digital Empowerment Efforts in Schools}

School authorities, teachers, and students at SMA Banda Aceh, Padang, and Banjarmasin schools respond differently to digital accessibility and ICT competence. They put in significant effort towards micro-digital empowerment and implementation adapted to each school's context and digital needs. The following table presents a matrix of the types of digital empowerment in the three schools:

Table 2: Types of Digital Empowerment in School

\begin{tabular}{|c|c|c|c|}
\hline $\begin{array}{l}\text { Types of Digital } \\
\text { Empowerment } \\
\text { in School }\end{array}$ & $\begin{array}{l}\text { SMA Lab School in } \\
\text { Banda Aceh }\end{array}$ & SMAN Padang & $\begin{array}{c}\text { SMAN } \\
\text { Banjarmasin }\end{array}$ \\
\hline \multirow[t]{4}{*}{$\begin{array}{l}\text { Digital } \\
\text { Competency } \\
\text { Training for } \\
\text { Teachers and } \\
\text { Students }\end{array}$} & $\begin{array}{l}\text { Form: Face-to-face } \\
\text { training in groups } \\
\text { with school computer } \\
\text { teachers as } \\
\text { presenters, and } \\
\text { discussion forum } \\
\text { with presenters from } \\
\text { outside the school. }\end{array}$ & $\begin{array}{l}\text { Form: Digital } \\
\text { socialisation } \\
\text { packaged in seminars } \\
\text { on digital } \\
\text { empowerment with } \\
\text { presenters from } \\
\text { universities, and } \\
\text { computer training } \\
\text { with ICT teachers as } \\
\text { facilitators. }\end{array}$ & $\begin{array}{l}\text { Form: Training or } \\
\text { workshops every } \\
\text { year with material } \\
\text { about technology. } \\
\text { Online-based } \\
\text { teacher } \\
\text { assignments and } \\
\text { strategies (e-report) } \\
\text { facilitated by two } \\
\text { computer teachers } \\
\text { with computer } \\
\text { training in a pilot. }\end{array}$ \\
\hline & $\begin{array}{l}\text { Targets: Teachers and } \\
\text { Students }\end{array}$ & Target: Teachers & Target: Teachers \\
\hline & $\begin{array}{l}\text { Material: Computer } \\
\text { operations and } \\
\text { applications } \\
\text { (Microsoft Word and } \\
\text { Microsoft } \\
\text { PowerPoint), and e- } \\
\text { learning. }\end{array}$ & $\begin{array}{l}\text { Material: How to } \\
\text { make learning media } \\
\text { elaborated following } \\
\text { the character and } \\
\text { teaching techniques } \\
\text { of each teacher; make } \\
\text { slides in Microsoft } \\
\text { PowerPoint and email } \\
\text { for some digital-based } \\
\text { subjects chosen by the } \\
\text { trainee teacher. }\end{array}$ & $\begin{array}{l}\text { Material: How to } \\
\text { use Microsoft } \\
\text { Word, Microsoft } \\
\text { Excel, and email. } \\
\text { However, } \\
\text { workshops with } \\
\text { similar material did } \\
\text { not continue } \\
\text { anymore because } \\
\text { there were no } \\
\text { teacher enthusiasts. }\end{array}$ \\
\hline & $\begin{array}{l}\text { Result: The teachers } \\
\text { already have their } \\
\text { laptops and can } \\
\text { operate the features } \\
\text { on the laptop } \\
\text { independently to } \\
\text { create digital learning } \\
\text { media. }\end{array}$ & $\begin{array}{l}\text { Results: The training } \\
\text { of the teachers had } \\
\text { increased skills in } \\
\text { operating technology } \\
\text { sets and their } \\
\text { application to make } \\
\text { learning media and } \\
\text { presenting material in } \\
\text { technology-based } \\
\text { classes. }\end{array}$ & Result: Unknown. \\
\hline
\end{tabular}




\begin{tabular}{|c|c|c|c|}
\hline $\begin{array}{l}\text { Types of Digital } \\
\text { Empowerment } \\
\text { in School }\end{array}$ & $\begin{array}{l}\text { SMA Lab School in } \\
\text { Banda Aceh }\end{array}$ & SMAN Padang & $\begin{array}{c}\text { SMAN } \\
\text { Banjarmasin }\end{array}$ \\
\hline $\begin{array}{l}\text { Transfer of } \\
\text { Digital } \\
\text { Knowledge ICT } \\
\text { and Practice } \\
\text { between } \\
\text { Teachers and } \\
\text { Students }\end{array}$ & $\begin{array}{l}\text { Form: Helps teachers } \\
\text { use technology } \\
\text { devices in the } \\
\text { classroom, such as } \\
\text { laptops and } \\
\text { projectors. }\end{array}$ & $\begin{array}{l}\text { Form: Helps teachers } \\
\text { with difficulty to } \\
\text { rename a document } \\
\text { and make } \\
\text { presentations in } \\
\text { Microsoft } \\
\text { PowerPoint. }\end{array}$ & $\begin{array}{l}\text { Form: Delivering } \\
\text { information in the } \\
\text { form of lessons or } \\
\text { competitions from } \\
\text { the internet to the } \\
\text { teacher. }\end{array}$ \\
\hline $\begin{array}{l}\text { Digital Literacy } \\
\text { for Students }\end{array}$ & $\begin{array}{l}\text { Form: The school has } \\
\text { not deepened digital } \\
\text { literacy, such as } \\
\text { enacting the } \\
\text { information and } \\
\text { transaction electronic } \\
\text { (ITE) Law in schools. }\end{array}$ & $\begin{array}{l}\text { Form: Appealing } \\
\text { about digital ethics to } \\
\text { students in the class, } \\
\text { such as how to deal } \\
\text { with hoaxes. Provide } \\
\text { information about } \\
\text { password security of } \\
\text { a student's digital } \\
\text { account. }\end{array}$ & $\begin{array}{l}\text { Form: Provision of } \\
\text { information on } \\
\text { hoaxes to students } \\
\text { in the classroom by } \\
\text { a school computer } \\
\text { teacher, urged } \\
\text { students not to } \\
\text { create creative } \\
\text { content related to } \\
\text { the government; } \\
\text { information about } \\
\text { copyright in } \\
\text { making creative } \\
\text { content; } \\
\text { Information about } \\
\text { scamming in } \\
\text { activities in the } \\
\text { digital world. }\end{array}$ \\
\hline $\begin{array}{l}\text { Digital Activity } \\
\text { Assistance for } \\
\text { Students }\end{array}$ & $\begin{array}{l}\text { Form: The school } \\
\text { urges parents to pay } \\
\text { attention to the digital } \\
\text { activities of children } \\
\text { at home because the } \\
\text { school is not a place } \\
\text { to care for and } \\
\text { improve children's } \\
\text { behaviour to be better } \\
\text { individuals; the } \\
\text { school conducts a } \\
\text { sudden raid on } \\
\text { students' electronic } \\
\text { devices in class. }\end{array}$ & $\begin{array}{l}\text { Form: The teacher } \\
\text { encourages students } \\
\text { to carry out digital } \\
\text { activities positively; } \\
\text { the teacher builds } \\
\text { students' thinking so } \\
\text { that they can control } \\
\text { themselves and take } \\
\text { responsibility for } \\
\text { themselves in their } \\
\text { activities in the digital } \\
\text { world. }\end{array}$ & $\begin{array}{l}\text { Form: SMA } \\
\text { Banjarmasin guides } \\
\text { the teachers to } \\
\text { monitor learning } \\
\text { and student } \\
\text { activities through } \\
\text { the school's } \\
\text { academic website. } \\
\text { Students working } \\
\text { in the creative field } \\
\text { often solicit } \\
\text { computer } \\
\text { development } \\
\text { teachers' opinions } \\
\text { before publishing } \\
\text { their work on } \\
\text { YouTube. }\end{array}$ \\
\hline
\end{tabular}

Source: Irwansyah, 2020

Table 2 above presents the types of digital empowerment conducted by the school authority, teachers, and students in respective schools. Teachers help organise digital empowerment through competency training for fellow teachers and students and digital literacy and assistance for students. Empowerment is formed 
and implemented based on digital access, the schools' financial capacity, the absorption of digital knowledge, and teachers' and students' needs. The digital socio-cultural context in each school shapes teachers, students, and the perspective of authorities' and behaviour towards digital technology and empowerment. The forms and materials of digital empowerment in each school are adjusted following the teaching and learning techniques. This adjustment can be created via a two-way communication process on the competencies, initiatives, and digital barriers in the teaching-learning process. The communication process helps to shape teachers' and students' self-awareness with varied digital access and competencies, though they are in the same learning ecosystem. Selfawareness drives the teachers and students to share knowledge and practices integrated into various subjects' through digital collaboration.

\subsection{Discussion: Reflexivity Study on Digital Collaboration between Students and Teachers in Teaching and Learning Activities}

The integration of digital technology in the education system requires teachers and students to facilitate digital-based learning following the introduction of the 2013 Education Curriculum. Practically, this enactment is not similar in all schools in the context of Indonesia since it varies based on the social-cultural context, needs, and digital accessibility. For this reason, two situations arise from the efforts to integrate ICT in learning in schools both in terms of the inequality and the adaptation of ICT.

There is no doubt that teachers and students are involved in a digital learning ecosystem (Sarnok, Wannapiroon, \& Nilsook, 2019) and experience gaps in adapting ICT, and carrying out direct and two-way digital collaboration actions (Lopes, Oliveira, \& Costa, 2015). Moreover, they assist each other in the use of ICT tools and share knowledge on digital literacy. This collaboration arises from their reflection on ICT access and competencies (Kopaiboon, Reungtrakul, \& Wongwanich, 2014).

According to reflexivity, humans make observations on primary individual behaviour in order to adjust and establish their fast-changing life systems; these changes in human behaviour occur consistently. Humans respond to situations in order to gain the development of self-abilities that are both useful now and in the future (Giddens, 2006). People with reflexivity ability exhibit dynamic and creative behaviour in order to meet their needs and societal changes (Elliott, 2014).

Students at SMA Banda Aceh, Padang, and Banjarmasin reflected on the gaps faced in ICT competency during the learning process (Kopaiboon et al., 2014). The ICT competency disparity between teachers and students; however, hindered the process of knowledge delivery in learning sessions (Samuel \& Zaitun, 2007). They respond to this challenge by sharing ICT knowledge on how to operate related devices and applications. For instance, when teachers had difficulty connecting a laptop to the projector, in order to create slides using Microsoft PowerPoint, or displaying slides on the projector screen, they were assisted by students with ICT knowledge and competencies.

The initiative of students to share knowledge and help operate ICT tools enabled the teachers to achieve good performance in applying such devices during 
learning. Mentoring helps teachers adapt their abilities to the needs of teaching (Cherian, 2007). Superior competence in a particular field and implementation is normally through direct collaboration between the teacher and the mentor. In the context of digital collaboration, students act as mentors to guide teachers in the transition to ICT-based teaching in the classroom. Therefore, self-evaluation forms reflective teaching.

Self-evaluation (Dewey, 1933; McNamara, O'Hara, Boyle, \& Sullivan, 2009); and mentoring (Cherian, 2007) are methods used by teachers, and students to engage in responsive teaching and learning. Self-evaluation requires teachers and students to assess such practices. However, it needs to be persistent in teachinglearning experiences to produce new perspectives and teaching-learning practices, such as integrating digital technology in classroom learning (McNamara et al., 2009).

Some ICT teachers in SMA Padang and Banjarmasin having useful ICT competencies, practice reflexivity by conducting digital literacy to students. Digital literacy was initially developed in the 1990s when information became more easily compiled, accessed, and disseminated through information technology networks (Bawden, 2001). An ICT teacher at SMA Banjarmasin, initialised as informant RD, discovered that about $60 \%$ of students lacked the understanding of data security and digital privacy. Therefore, the digital literacy material was shared among students on the avoidance of hoaxes, data privacy on the internet, data security on digital student accounts, content copyright, and scamming. According to informant RD, in creating email passwords, the use of birthdays, home addresses, or parents' names should be avoided in order to minimise password hacking. Students accessing online content such as songs, videos, and images on YouTube were also asked to pay attention to copyright and were advised not to trust strangers on the internet without having a transparent and verifiable background.

Digital collaboration is a form of digital empowerment that is due to teacher and student reflexivity towards ICT competencies and the need to conduct teaching and learn more responsively (Lopes et al., 2015). Moreover, it helps teachers to understand student behaviour and the different ways of learning to accommodate their responsibilities concerning digital culture and student pedagogy (Ramanan \& Mohamad, 2020). It also models students to be individuals having sensitivity to the differences surrounding them, aside from empowering them to become active and creative in fast-evolving digital technology (Bruno \& Canina, 2019). In many respects, students are directly involved as digital empowerment agents with meaningful learning experiences (Giddens, 2006).

Accordingly, schools should be transformed into learning communities that bring together learning activities, direction, and cooperation between teachers and students (Bransford, Brown, Cocking, Donovan, \& Pellegrino, 2000). From the findings of this study, it was shown that teachers and students upheld digital collaboration as community-centred digital empowerment. As such, the surrounding ecosystem provides space that allows practising digital skills interactively and cooperatively. 


\section{Conclusion}

This study examined digital collaboration between teachers and students concerning digital empowerment. The results show that self-reflection in teachers and students helps to shape ICT awareness and supporting initiatives. In other words, the critical sustainability of digital empowerment through digital collaboration in the teaching-learning context. However, in the context of Indonesia, future studies should develop an analysis unit to gain a much broader understanding of digital empowerment.

This study has both academic and practical contributions. Academically, it motivates further studies on digital empowerment in education from elementary to secondary schools. Advanced qualitative research may be used to focus on measuring instruments, unit of analysis, the geographical and socio-cultural context of informants, and analytical perspectives.

Practically, this research may help to motivate the government to initiate and implement digital empowerment policies for the education system in Indonesia. This study has explained about digital empowerment that focuses not only on the provision of sophisticated digital access but also on how the schools authority, teachers, and students receive and integrate digital technology in the learning ecosystem. The implementation of these policies can be based according to the community's socio-cultural context in various regions in Indonesia.

\section{Acknowledgement}

We are grateful for the support of research funding from PDUPT DIKTI No. NKB1519/UN2.R3.1/HKP.05.00/2019; NKB-132/UN2.RST/HKP.05.00/2020; NKB2731/UN2.RST/HKP.05.00/2020

\section{References}

Ahmad, S. (2014). Problematika kurikulum 2013 dan kepemimpinan instruksional kepala sekolah. Jurnal Pencerahan, 8(2), 98-108. Retrieved from http://www.jurnal.unsyiah.ac.id/JPP/article/download/2158/2111

Alshenqeeti, H. (2014). Interviewing as a data collection method: A critical review. English Linguistics Research, 3(1), 39-45. https://doi.org/10.5430/elr.v3n1p39

Aubert, N. B. (2013). Documentation of ICT usage for Maya development: A case study from Aguacatán, Guatemala. Noragric: Norwegian University of Life Science.

Austin, C. G. (2017). Personal connections in the digital age, second edition. In Consumption Markets \& Culture (Vol. https:// doi.org/10.1080/10253866.2015.1135538

Baker, L. M. (2006). Observation: A complex research method. Library Trends, 55(1), 171189. https://doi.org/10.1353/lib.2006.0045

Bawden, D. (2001). Information and digital literacies: A review of concepts. Journal of Documentation, 57(2), 218-259.

Birch, A., \& Irvine, V. (2009). Preservice teachers' acceptance of ICT integration in the classroom: Applying the UTAUT model. Educational Media International, 46(4), 3741. https:// doi.org/10.1080/09523980903387506

Boehm, A., \& Staples, L. H. (2004). Empowerment: The point of view of consumers. Families in Society: The Journal of Contemporary Social Services, 85(2), 270-280. https://doi.org/https://doi.org/10.1606/1044-3894.314

Bransford, J. D., Brown, A. L., Cocking, R. R., Donovan, M. S., \& Pellegrino, J. W. (2000). 
How experts differ from novices. In J. D. Bransford, A. L. Brown, R. R. Cocking, M. S. Donovan, \& J. W. Pellegrino (Eds.), How People Learn: Brain, Mind, Experience, and School (pp. 31-50). https://doi.org/10.17226/9853

Braun, V., \& Clarke, V. (2006). Using thematic analysis in psychology. Qualitative Research in Psychology, 3(2), 77-101. https://doi.org/10.1191/1478088706qp063oa

Bruno, C., \& Canina, M. (2019). Creativity 4.0. Empowering creative process for digitally enhanced people. Design Journal, 22(sup1), 2119-2131. https:// doi.org/10.1080/14606925.2019.1594935

Casal, C. R. (2007). ICT for education and development. In Info (Vol. 9). https://doi.org/10.1108/14636690710762093

Cherian, F. (2007). Learning to teach: Teacher candidates reflect on the relational, conceptual, and contextual influences of responsive mentorship. Canadian Journal of Education, 30(1), 25-46. https:// doi.org/10.2307/20466624

Cohen-Cole, J. (2005). The reflexivity of cognitive science: The scientist as model of human nature. History of the Human Sciences, 18(4), 107-139. https:// doi.org/10.1177/0952695105058473

Dewey, J. (1933). How We Think: A Restatement of the Relation of Reflective Thinking to the Educative Process. Massachusetts: D.C. Heath and Company.

Ekayanti, S. R., \& Irwansyah. (2019). UTAUT in communication technology of learning management system. 2018 International Conference on Advanced Computer Science and Information Systems, ICACSIS 2018, 253-258. https:// doi.org/10.1109/ICACSIS.2018.8618172

Elliott, A. (2014). Concepts of The Self (3rd ed.). Malden, MA: Malden, MA: Polity Press.

Ertmer, P. A. (1999). Addressing first-and second-order barriers to change: Strategies for technology integration. Educational Technology Research and Development, 47(4), 4761. https://doi.org/10.1007/BF02299597

Ertmer, P. A. (2003). Transforming teacher education: Visions and strategies. Educational Technology Research and Development, 51(1), 124-128. https://doi.org/10.1007/BF02504522

Ferguson, H. (1997). Protecting children in new times: Child protection and the risk society. Child and Family Social Work, 2(4), 221-234.

Ferguson, H. (2003). Welfare, social exclusion, and reflexivity: The case of child and woman protection. Journal of Social Policy, 32(2), 199-216. https://doi.org/http://dx.doi.org/10.1017/S0047279402006967

Fitriyadi, H. (2013). Integrasi teknologi informasi komunikasi dalam pendidikan: Potensi manfaat, masyarakat berbasis pengetahuan, pendidikan nilai, strategi implementasi, dan pengembangan profesional. Jurnal Pendidikan Teknologi Dan Kejuruan, 21(3), 269-284. https://doi.org/https://doi.org/10.21831/jptk.v21i3.3255

Giddens, A. (1990). The Consequences of Modernity. Cambridge: Polity Press.

Giddens, A. (2006). Sociology. Cambridge: Polity Press.

Gray, T. (2003). Rich ICT learning experiences: What do they look. Enabling E-Learning, 18. Retrieved from http://elearning.tki.org.nz/Media/Files/Rich-ICT-learningexperiences-What-do-they-look-like2

Hage, A. M., \& Lorensen, M. (2005). A philosophical analysis of the concept empowerment; the fundament of an education-programme to the frail elderly. Nursing Philosophy, 6(4), 235-246. https://doi.org/10.1111/j.1466769X.2005.00231.x

Hermawati. (2020). Teachers' efforts in understanding the factual, conceptual, procedural, and metacognitive assessment using the revised 2013 curriculum. International 
Journal of Learning, Teaching and Educational Research, 19(5), 186-199. https://doi.org/10.26803/ijlter.19.5.11

Honan, E. (2008). Barriers to Teachers Using Digital Texts in Literacy Classrooms. Literacy, 4(21), 36-43. https://doi.org/10.1111/j.1467-9345.2008.00480.x

Hur, M. H. (2006). Empowerment in terms of theoretical perspectives: Exploring a typology of the process and components across disciplines. Journal of Community Psychology, 34(5), 523-540. https://doi.org/10.1002/jcop

Irwansyah, I., \& Triputra, P. (2016). Indonesia gastronomy brand: Netnography on virtual culinary community. The Social Sciences, 11(19), 4585-4588. https://doi.org/10.3923/sscience.2016.4585.4588

Jones, A. (2004). A review of the research literature on barriers to the uptake of ICT by teachers. British Educational Communications and Technology Agency (Becta), 1(June), 1-29. $\quad$ Retrieved from http://dera.ioe.ac.uk/1603/1/becta_2004_barrierstouptake_litrev.pdf

Kopaiboon, W., Reungtrakul, A., \& Wongwanich, S. (2014). Developing the quality of ICT competency instruments for lower secondary school students. Procedia - Social and Behavioral Sciences, 116(October), 1802-1809. https:// doi.org/10.1016/j.sbspro.2014.01.475

Kuyoro, A., Awodele, O., \& Samuel, O. (2012). ICT: An effective tool in human development. International Journal of Humanities and Social Science, 2(7), 157-162. Retrieved

from http://www.ijhssnet.com/journals/Vol_2_No_7_April_2012/17.pdf

Levene, M. (2010). An introduction to search engines and web navigation. Hoboken, New Jersey: John Wiley \& Sons, Inc.

Lopes, I., Oliveira, A., \& Costa, C. J. (2015). Tools for online collaboration: Do they contribute to improve teamwork? Mediterranean Journal of Social Sciences, 6(6 S4), 511-517. https://doi.org/10.5901/mjss.2015.v6n6s4p511

Lowther, D. L., Inan, F. A., Strahl, J. D., \& Ross, S. M. (2008). Does technology integration "work" when key barriers are removed? Educational Media International, 45(3), 195213. https:// doi.org/10.1080/09523980802284317

Mäkinen, M. (2006). Digital empowerment as a process for enhancing citizens participation. E-Learning and Digital Media, 3(3), 381-395. https:// doi.org/10.2304/elea.2006.3.3.381

McNamara, G., O'Hara, J., Boyle, R., \& Sullivan, C. (2009). Developing a culture of evaluation in the Irish public sector: The case of education. Evaluation, 15(1), 101112. https://doi.org/10.1177/1356389008095492

Miles, M. B., \& Huberman, A. M. (1994). Qualitative data analysis: An expanded sourcebook (2nd ed.). London, UK: SAGE Publications, Inc.

Payne, M. (1997). Modern social work theory. London: MacMillan Press.

Prensky, M. (2001). Digital natives, digital immigrants. On the Horizon, 9(5), 1-6.

Ramanan, B., \& Mohamad, M. Bin. (2020). Validating a model of change readiness among Malaysian school teachers: A structural equation modeling approach. International Journal of Learning, Teaching and Educational Research, 19(2), 79-93. https:// doi.org/10.26803/ijlter.19.2.6

Safira, M. R., \& Irwansyah, I. (2019). The social humanism factor in digital empowerment in Indonesia. 2019 International Conference on Advanced Computer Science and Information Systems (ICACSIS), 409-416. https://doi.org/10.1109/ICACSIS47736.2019.8979911

Saleebey, D. (2006). Strengths perspective in social work practice. Boston: Allyn \& Bacon.

Samuel, R. J., \& Zaitun, A. B. (2007). Do teachers have adequate ICT resources and the 
right ICT skills in integrating ICT tools in the teaching and learning of the English language in Malaysian schools? The Electronic Journal of Information Systems in Developing Countries, 29(1), 1-15. https://doi.org/10.1002/j.16814835.2007.tb00196.x

Sánchez, J. J. C., \& Alemán, E. C. (2011). Teachers' opinion survey on the use of ICT tools to support attendance-based teaching. Computers $\mathcal{E}$ Education, 56(3), 911-915. https://doi.org/10.1016/j.compedu.2010.11.005

Sarnok, K., Wannapiroon, P., \& Nilsook, P. (2019). Digital learning ecosystem by using digital storytelling for teacher profession students. International Journal of Information and Education Technology, 9(1), 21-26. https://doi.org/10.18178/ijiet.2019.9.1.1167

Staples, L. H. (1990). Powerful ideas about empowerment. Administration in Social Work, 14(2), 29-42. https://doi.org/10.1300/J147v14n02

Teo, T. (2008). Pre-service teachers' attitudes towards computer use: A Singapore survey. Australasian Journal of Educational Technology, 24(4), 413-424. https://doi.org/https://doi.org/10.14742/ajet.1201

UNESCO. (2007). The UNESCO ICT in education programme. Bangkok: UNESCO, Thailand.

Weckert, J., \& Lucas, R. (2017). Professionalism in the information and communication technology industry. In Professionalism in the Information and Communication Technology Industry. https://doi.org/10.26530/oapen_459997

Yeasmin, S., \& Rahman, K. F. (2012). "Triangulation" research method as the tool of social science research. Bup Journal, 1(1), 154-163. Retrieved from http://www.bup.edu.bd/journal/154-163.pdf 